\title{
Examining Inquiry-Based Learning Stages of Concern for High School Agriscience Teachers
}

N. Conner ${ }^{1}$, B. Reiling ${ }^{2}$, C. Stripling ${ }^{3}$, M. Kreifels ${ }^{4}$, A. Monheim ${ }^{5}$

\begin{abstract}
There is documented need for improvement of science comprehension amongst high school students in the United States, and inquiry-based learning (IBL) is a recommended teaching strategy to improve science comprehension. Several researchers have focused on examination of learning outcomes for students, but few have researched the concerns of teachers who may wish to adopt IBL methodology. This study used the stages of concern questionnaire to profile ten Midwest high school agriscience teachers' concerns regarding implementation of IBL, before and after participation in a year-long professional development program where IBL lessons were developed and used in the participants' high school classrooms. Results indicated that while some participants showed a positive progression in their stage of concern, most professional development program participants did not progress in their concern stage, and some developed increased resistance to IBL as a teaching strategy. This suggests that teachers may need more robust and tailored support when adopting IBL for their classrooms.
\end{abstract}

\section{Keywords}

scientific investigation, secondary teachers, professional development

1. Nathan W. Conner, Associate Professor, University of Nebraska-Lincoln, 236 Filley Hall, Lincoln, NE 68583-0947, nconner2@unl.edu, https://orcid.org/0000-0003-0063-4110

2. Bryan Reiling, Associate Professor, University of Nebraska-Lincoln, ANSC C204a, Lincoln, NE 68583-0947, breiling2@unl.edu, https://orcid.org/0000-0002-5913-0614

3. Christopher T. Stripling, Associate Professor, The University of Tennessee, 320 Morgan Circle Drive, Knoxville, TN $37996-$ 4511, cstripli@utl.edu, http://orcid.org/0000-0002-5045-3492

4. Matt Kreifels, Associate Professor of Practice, University of Nebraska-Lincoln, 233 Filley Hall, Lincoln, NE 68583-0947, matt.kreifels@unl.edu, http://orcid.org/0000-0002-6519-8711

5. Angie Monheim, Graduate Student, University of Nebraska-Lincoln, 143 Filley Hall, Lincoln, NE 68583-0947, amonheim@ieee.org, http://orcid.org/0000-0002-8596-9448 


\section{Introduction and Problem Statement}

High school science student proficiency in the United States lags compared to other highly developed countries (Desilver, 2017; Organisation for Economic Co-operation and Development, 2016; The Nation's Report Card, 2015). Research comparing Science, Technology, Engineering, and Mathematics (STEM) jobs versus unemployed STEM workers showed a national average of 13 STEM jobs posted online for everyone unemployed STEM worker, and that four Midwest states had more than 45 posted STEM jobs per unemployed STEM worker (New American Economy, 2017). These statistics indicate that an inadequate number of students are gaining necessary proficiency in high school science to facilitate successful transition to STEM based jobs in the work force.

One means of addressing this deficit is to provide high school science and agriculture teachers with targeted professional development programs focused on science teaching strategies. One program in a Midwest state used grant funding to provide a rigorous year-long professional development program designed to help high school science and agriculture teachers learn how to use and implement inquiry-based learning (IBL) to teach specific science subjects.

Inquiry-based learning is a teaching strategy shown to provide significant benefits for development of critical thinking and problem-solving skills in students (Savery, 2006), but the literature is sparse on how teachers feel about adopting this teaching strategy. The purpose of this study was to determine the stages of concern experienced by high school teachers before and after adopting IBL as a classroom teaching strategy for science subjects.

\section{Theoretical and Conceptual Framework}

The theoretical framework for this study was the Concerns Based Adoption Model (CBAM) which is a framework designed to help implement and assess innovations or changes being implemented in an organization (American Institute for Research, 2019). This model has a robust history (Southwest Educational Development Laboratory, 2015), and has been critically examined and reviewed by scholars (Anderson, 1997; Cheung et al., 2001; Saunders, 2012. The framework has three parts, Innovation Configurations, Stages of Concern Questionnaire (SOCQ), and Levels of Use (Southwest Educational Development Laboratory, 2015). This study focused on the SOCQ to determine how high school teachers feel about adopting IBL as a teaching strategy.

The SOCQ is an assessment instrument to help understand how teachers experience the adoption of new teaching strategies (Bailey \& Palsha, 1992; Gabby et al., 2017; Shotsberger \& Crawford, 1999) using seven categories which indicate increasing levels of concern: unconcerned, informational, personal, management, consequence, collaboration, and refocusing (George et al., 2013). More specifically, it has a history of being used to assess the concerns of agricultural educators as innovations are introduced into their teaching pedagogies (Bellah \& Dyer, 2009; Shoulders \& Myers, 2011; Warner \& Myers, 2011). 


\section{Inquiry-based Learning}

Inquiry-based learning is a guided active learning strategy that encourages students to develop questioning, critical thinking, and problem-solving skills (Savery, 2006), and has been shown to provide measurable gains in student conceptual understanding of science lessons (Geier et al., 2008; Gormally et al., 2009; Luckie et al., 2004; Sundberg \& Moncada, 1994; Udovic et al., 2002). However, this appears only to be true when students receive enough guided instruction, as Kirschner et al. (2006) showed IBL with minimal guidance resulted in no improvement or, in some cases, learning less and testing worse, than with traditional instruction.

While the educational impact of IBL on students is widely studied, often ignored are the potential struggles of high school teachers who attempt to adopt IBL as a teaching strategy. Keys and Bryan (2001) argue that more research is needed on teacher beliefs about, practices, and knowledge base for implementing IBL. Although $90 \%$ of pre-service teachers who participated in an inquiry-based science methods course want to create an educational environment that promotes questions and exploration (Plevyak, 2007), they were simultaneously overwhelmed with how to accomplish that goal. Two separate studies (DiBiase \& McDonald 2015; Ramnarain, 2014) found factors such as lack of resources or administrative support, class size, and curricular requirements contributed to teacher resistance to using IBL. Roehrig and Luft (2004) followed 14 beginning secondary science teachers for one year; common impediments to implementation of IBL included their understanding of scientific inquiry, content knowledge, pedagogical content knowledge, and teaching beliefs. Hayward et al. (2015) suggests that presenting IBL as a broad set of related practices rather than as a rigid prescriptive practice, may encourage new instructors to incorporate IBL into their own sense of teaching identity.

\section{Purpose}

The purpose of this study was to determine the stages of concern (SOC) experienced by high school teachers before and after participation in a professional development program for using IBL as a classroom teaching strategy for science subjects. In order to achieve this purpose, the following objectives were investigated:

1. Determine participants' SOC for IBL at the beginning of the professional development program.

2. Determine participants' SOC for IBL at the end of the professional development program.

3. Assess change(s) that occurred in participants' SOC for IBL as a result of the professional development program.

\section{Methods}

This study was conducted as part of a grant-funded, year-long (July 2017 thru July 2018) Professional Development (PD) workshop for high school agriculture and science educators using IBL to teach science topics. The instrument used for this study was the SOCQ (George, et 
al., 2013) which measures teacher concerns as they adopt a change. In this study, the change under study was the adoption of IBL into their teaching techniques. According to George et al. (2013) the SOCQ has went through rigorous validation efforts through the use of correlation matrices, factor analysis, and interviews. Participants began the workshop by taking the SOCQ to establish their stage of concern before the PD. During the year-long PD, participants had the opportunity to 1) experience IBL from the student perspective, 2) teach a pre-developed IBL lesson for a specific science topic with other participants at the workshop, 3) return to their home schools and use IBL lessons as part of the curriculum in their actual classrooms with scheduled monthly online support meetings with workshop facilitators to answer questions about IBL, and 4) attend a follow-up in-person workshop session to teach an IBL lesson of their own design to the workshop participants for feedback. At the end of the PD, participants again took the SOCQ to determine if the PD had any effect on their stage of concern for adopting IBL. The results from the two SOCQ surveys are the data used for this study.

Twenty-seven participants began the workshop, but only 10 completed the entire professional development program, including the pre- and post- SOCQ. Attrition of participants was attributed to various reasons including physical and career moves, time constraints, and priority selection. Due to the low sample size, use caution when interpreting the data.

To evaluate how stages of concern changed for participants, it was necessary for participants to have completed both the pre- and post-SOCQ instruments. Data from participants who did not complete the post professional development program SOCQ instrument were discarded. The analysis was conducted according to the SOCQ manual (George et al., 2013), and focused on profile scoring which provides the richest understanding of participants' concerns about the innovation. Analysis by demographic was not conducted due to the small sample size. Results from individual profiles were not confirmed with participants because scoring and analysis of the SOCQ were performed a few months after conclusion of the professional development program so participants were no longer available for discussion.

When interpreting Profile Scores, the SOCQ manual (Hall et al., 1979) provides specific characteristics to look for among the highs and lows, which indicate a possible underlying psychology. For IBL in the classroom, these characteristics are as follows:

- High stage 0 percentile score is an indication that the participants place a low priority on $\mathrm{IBL}$ in relation to other teaching tasks and strategies.

- Positive 1-2 splits indicate participants are open to using IBL.

- Negative 1-2 splits indicate participants may be resistive to using IBL.

- Stage 6 trailing up indicates participants may be resistive to using IBL.

- Stage 6 trailing down indicates that participants may be open to using IBL.

- High stage 0 with high stage 6 indicates the participant has ideas about other teaching methods considered more relevant than IBL. 
- When two stages have a percentile score within one or two points of each other, both stages can be considered the highest or second highest stage.

The above characteristics were used to interpret the group and individual profiles for this study.

\section{Findings}

Objective 1 was to determine participants' SOC before the professional development program, objective 2 was to determine participants' SOC after the professional development program, and objective 3 was to analyze the change in SOC attributed to the professional development program. This was performed for the group, then performed for each individual participant.

\section{Group Analysis}

Figure 1 shows the group profile before (solid black line) and after (dashed grey line) the professional development program. At the beginning of the professional development program, the group generally placed a low priority on IBL, as indicated by the relatively high stage 0 score. The before profile also showed both a positive 1-2 split and stage 6 trailing down, indicating that the group was generally open to IBL. After the professional development program, the stage 0 score remained relatively high, indicating the group generally still placed a low priority on IBL. The positive 1-2 split remained, indicating openness to IBL, but stage 6 was trailing up indicating resistance to IBL. The overall change in the profile indicates that as a group, participants did not progress positively in their stage of concern and may have added some resistance to using IBL as a teaching strategy as a result of participating in the professional development program. 


\section{Figure 1}

Before and After SOCQ Profiles for the Group

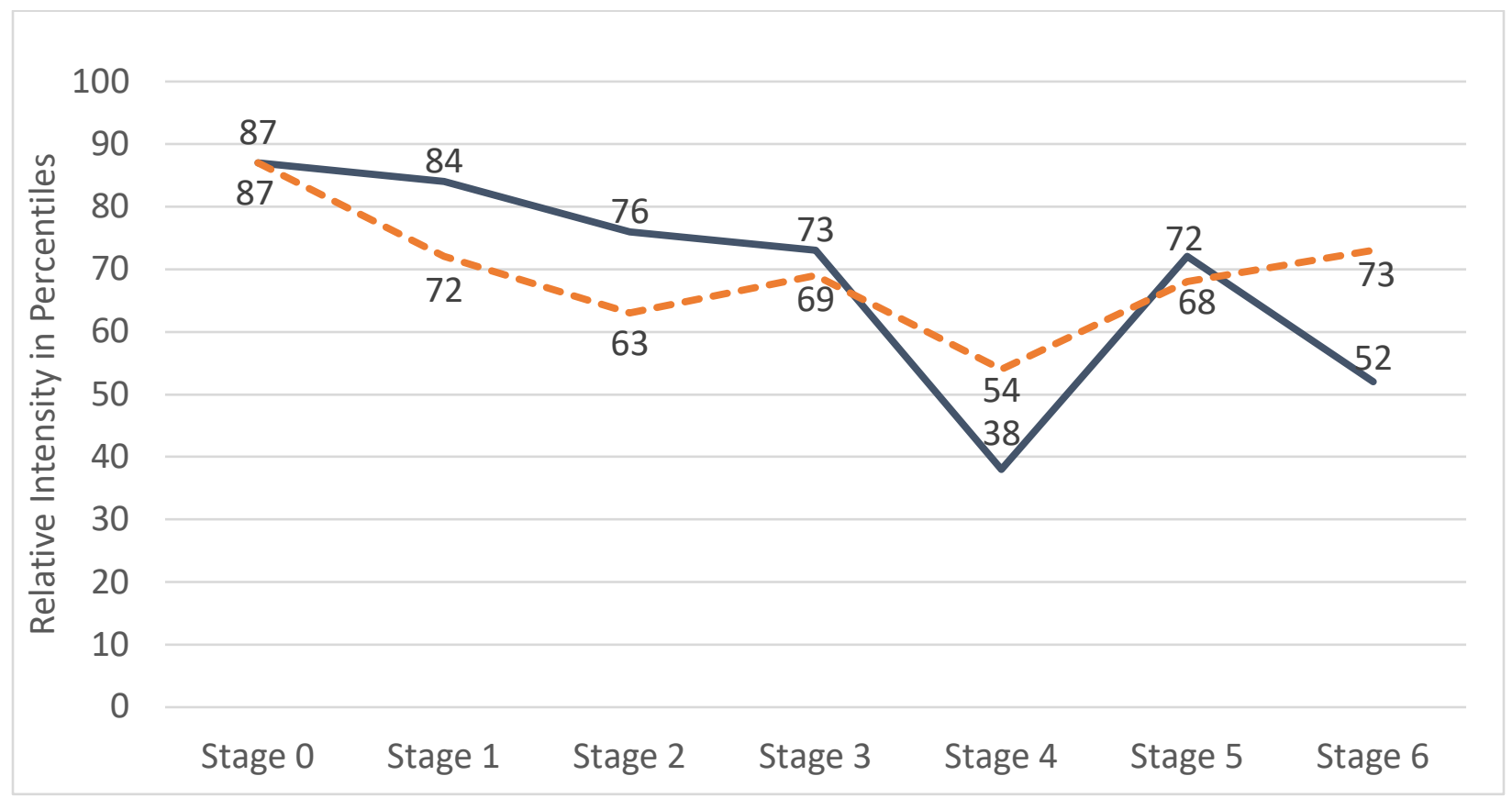

The solid line shows the profile percentages for each stage of concern for the group at the beginning of the professional development program. The dashed line shows the profile percentages for each stage of concern for the group after completing the professional development program.

\section{Individual Profile Score}

An analysis of the individual profile scores provided more insight into how the professional development program affected individual participants. Participants fell into three categories: No change, positive SOC progression, or no stage change with a change in profile characteristics. One participant showed no change. Three participants showed a positive SOC progression. Six participants showed no stage change with a change in profile characteristics. These profile changes included the emergence or receding of management concerns about IBL, and the emergence of resistance to IBL. Table 1 shows a summary of the before profile, after profile, and change in profile for each of the ten participants. 


\section{Table 1}

Summary of Before and After SOCQ Profile Interpretations and Profile Changes for Individual Professional Development Program Participants

\begin{tabular}{|c|c|c|c|}
\hline ID & $\begin{array}{l}\text { Before Profile } \\
\text { Interpretation } \\
\end{array}$ & $\begin{array}{l}\text { After Profile } \\
\text { Interpretation } \\
\end{array}$ & Change in Profile \\
\hline P1 & $\begin{array}{l}\text { IBL is low priority but } \\
\text { likely open to IBL }\end{array}$ & $\begin{array}{l}\text { IBL is low priority with } \\
\text { management concerns, } \\
\text { likely open to IBL }\end{array}$ & $\begin{array}{l}\text { Remained Stage } 0 \text {, concerns } \\
\text { about management } \\
\text { emerged }\end{array}$ \\
\hline $\mathbf{P} 2$ & $\begin{array}{l}\text { IBL is low priority but } \\
\text { likely open to IBL }\end{array}$ & $\begin{array}{l}\text { Focused on learning more } \\
\text { about IBL and } \\
\text { collaborating with others }\end{array}$ & SOC progressed from 0 to 1 \\
\hline P3 & $\begin{array}{l}\text { IBL is low priority but } \\
\text { likely open to IBL }\end{array}$ & $\begin{array}{l}\mathrm{IBL} \text { is low priority and likely } \\
\text { resistant to IBL }\end{array}$ & $\begin{array}{l}\text { Remained Stage } 0 \text { and } \\
\text { added resistance to IBL }\end{array}$ \\
\hline P4 & $\begin{array}{l}\text { IBL is low priority but } \\
\text { likely open to IBL }\end{array}$ & $\begin{array}{l}\text { Focused on learning more } \\
\text { about IBL and } \\
\text { management of IBL }\end{array}$ & $\begin{array}{l}\text { SOC progressed from } 0 \text { to } \\
1 / 3\end{array}$ \\
\hline P5 & $\begin{array}{l}\text { IBL is low priority with } \\
\text { management concerns, } \\
\text { likely open to IBL }\end{array}$ & $\begin{array}{l}\mathrm{IBL} \text { is low priority but likely } \\
\text { resistant to IBL }\end{array}$ & $\begin{array}{l}\text { Remained Stage } 0 \text { and } \\
\text { added resistance to IBL }\end{array}$ \\
\hline P6 & $\begin{array}{l}\mathrm{IBL} \text { is low priority and } \\
\text { likely resistant to IBL }\end{array}$ & $\begin{array}{l}\text { IBL is low priority with } \\
\text { management concerns, } \\
\text { likely resistant to IBL }\end{array}$ & $\begin{array}{l}\text { Remained Stage } 0 \text {, concerns } \\
\text { about management } \\
\text { emerged }\end{array}$ \\
\hline P7 & $\begin{array}{l}\text { IBL is low priority but } \\
\text { likely open to IBL }\end{array}$ & $\begin{array}{l}\text { IBL is low priority but likely } \\
\text { open to IBL }\end{array}$ & No discernable change \\
\hline P8 & $\begin{array}{l}\text { Focused on collaborating } \\
\text { with others and learning } \\
\text { more about IBL }\end{array}$ & $\begin{array}{l}\text { Focused on gaining more } \\
\text { benefits by modifying or } \\
\text { replacing } I B L \text {, and } \\
\text { collaborating with others }\end{array}$ & SOC progressed from 5 to 6 \\
\hline P9 & $\begin{array}{l}\text { IBL is low priority with } \\
\text { management concerns, } \\
\text { likely resistant to IBL }\end{array}$ & $\begin{array}{l}\mathrm{IBL} \text { is low priority but likely } \\
\text { resistant to IBL }\end{array}$ & $\begin{array}{l}\text { Remained Stage } 0 \text {, } \\
\text { management concerns } \\
\text { receded }\end{array}$ \\
\hline P10 & $\begin{array}{l}\text { IBL is low priority but } \\
\text { likely open to IBL }\end{array}$ & $\begin{array}{l}\mathrm{IBL} \text { is low priority but likely } \\
\text { resistant to IBL }\end{array}$ & $\begin{array}{l}\text { Remained Stage } 0 \text { but } \\
\text { added resistance to IBL }\end{array}$ \\
\hline
\end{tabular}




\section{Conclusions, Discussion, and Recommendations}

High school teachers adopting IBL initially appeared to be open to the new teaching strategy as evidenced both by their willingness to participate in a year-long PD program and their pre-PD program responses to a SOCQ. However, after participating in the PD program, results were mixed. $30 \%$ of participants had their concerns stage progressed by one stage after completing the PD program. However, $70 \%$ of the participants remained at stage zero, and three of those seven showed increased resistance to adoption of IBL in their SOCQ profiles after completing the PD program. While the PD program structure may have helped some participant's progress positively in their concerns stages towards IBL, many of the participants may have increased resistance to IBL.

Warner and Myers (2011) described Hall and Hord's Concerns-Based Adoption Model, of which the SOCQ is an integral part, as applied to implementing change in agriscience teaching. They describe that positive concerns progression can be achieved and resistance to change can be reduced with appropriate interventions, such as appropriate support from leaders and effective facilitation. However, they also explain that lack of progression or even regression can occur when these conditions do not exist.

An examination of this PD program revealed several factors which may have caused participants to not fully embrace IBL as a teaching strategy. Experience levels of PD program participants varied greatly, with some participants at the beginning of their teaching careers and some participants possessing many years of teaching experience. Professional development program facilitators noted that newer teachers seemed to like IBL better than more seasoned teachers, potentially indicating that newer teachers were less resistive than teachers with more experience. Shoulders and Myers (2011) found that more experienced teachers have less variation in their concerns for IBL. This could explain some of the $70 \%$ of profiles that did not progress positively.

Another factor that may have contributed was familiarity with the specific science subjects. PD program facilitators observed that some participants were more well versed in the science subject area content than others. Fritz and Miller (2003) found that over 50\% of the concerns expressed by both male and female preservice teachers were related to self-adequacy, of which one component is subject matter adequacy. It may be helpful to ensure teachers have experience teaching specific content areas prior to attempting the subject areas with IBL.

Online collaboration meetings, conducted via Zoom, were designed to provide an opportunity for participants to share their experiences and discuss any IBL teaching issues with facilitators and other participants. However, teachers chose to incorporate the specific content areas and associated pre-developed IBL lessons at different points in their course curriculums, resulting in disjointed Zoom meetings. Future PD programs should consider using a more detailed schedule and due dates for participants to have taught each subject area in their classrooms to ensure Zoom collaborations have a common theme on which to focus discussion. 
These findings suggest some recommendations for future studies aimed at effectively improving future PDs for introducing IBL to high school teachers. Teacher Stages of Concern need to be researched over a longer period of time and in conjunction with the specific environments and contexts individual teachers must navigate at their specific schools. Additionally, SOCQ results should be examined to determine if environmental and context factors show any correlation with specific SOCQ profiles. Results from these types of studies could provide insight into how schools can better support teachers as they adopt IBL.

\section{Acknowledgements}

We would like to acknowledge and thank Nebraska's Coordinating Commission for Postsecondary Education for funding this research.

\section{References}

American Institute for Research. (2019, March 11). CBAM: The concerns-based adoption model. https://www.air.org/resource/concerns-based-adoption-model-cbam

Anderson, S. E. (1997). Understanding teacher change: Revisiting the concerns based adoption model. Curriculum Inquiry, 27(3), 331-367. https://doi.org/10.1080/03626784.1997.11075495

Bailey, D. B., \& Palsha, S. A. (1992). Qualities of the stages of concern questionnaire and implications for educational innovations. The Journal of Educational Research, 85(4), 226-232. https://doi.org/10.1080/00220671.1992.9941120

Bellah, K., \& Dyer, J. (2009). Attitudes and stages of concern of elementary teachers toward agriculture as a context for teaching across grade level content area standards. Journal of Agricultural Education, 50(2), 12-25. https://doi.org/10.5032/jae.2009.02012

Cheung, D., Hattie, J., \& Ng, D. (2001). Reexamining the stages of concern questionnaire: A test of alternative models. The Journal of Educational Research, 94(4), 226-236. https://doi.org/10.1080/00220670109598756

Desilver, D. (2017, February 15). U.S. academic achievement lags that of many other countries. https://www.pewresearch.org/fact-tank/2017/02/15/u-s-students-internationallymath-science/

DiBiase, W., \& McDonald, J. R. (2015). Science teacher attitudes toward inquiry-based teaching and learning. The Clearing House: A Journal of Educational Strategies, Issues and Ideas, 88(2), 29-38. https://doi.org/10.1080/00098655.2014.987717 
Fritz, C. A., \& Miller, G. S. (2003). Concerns expressed by student teachers in agriculture. Journal of Agricultural Education, 44(3), 47-53. https://doi.org/10.5032/jae.2003.03047

Gabby, S., Avargil, S., Herscovitz, O., \& Dori, Y. J. (2017). The case of middle and high school chemistry teachers implementing technology: Using the concerns-based adoption model to assess change processes. Chemistry Education Research and Practice, 18(1), 214-232. https://doi.org/10.1039/c6rp00193a

George, A., Hall, G., \& Stiegelbauer, S. (2013). Measuring implementation in schools: The stages of concern questionnaire. SEDL https://sedl.org/cbam/socq manual 201410.pdf

Gormally, C., Brickman, P., Hallar, B., \& Armstrong, N. (2009). Effects of inquiry-based learning on students' science literacy skills and confidence. International Journal for the Scholarship of Teaching and Learning, 3(2), 1-22. https://doi.org/10.20429/ijsotl.2009.030216

Geier, R., Blumenfeld, P. C., Marx, R. W., Krajcik, J. S., Fishman, B., Soloway, E., \& ClayChambers, J. (2008). Standardized test outcomes for students engaged in inquiry-based science curricula in the context of urban reform. Journal of Research in Science Teaching, 45(8), 922-939. https://doi.org/10.1002/tea.20248

Hall, G. E., George, A. A., \& Rutherford, W. L. (1979). Measuring stages of concern about the innovation: A manual for use of the SOC Questionnaire (Report No. 3032). Research and Development Center for Teacher Education, The University of Texas at Austin. https://files.eric.ed.gov/fulltext/ED147342.pdf

Hayward, C. N., Kogan, M., \& Laursen, S. L. (2015). Facilitating instructor adoption of inquirybased learning in college mathematics. International Journal of Research in Undergraduate Mathematics Education, 2(1), 59-82. https://doi.org/10.1007/s40753015-0021-y

Keys, C. W., \& Bryan, L. A. (2001). Co-constructing inquiry-based science with teachers: Essential research for lasting reform. Journal of Research in Science Teaching, 38(6), 631-645. https://doi.org/10.1002/tea.1023

Kirschner, P.A., Sweller, J., \& Clark, R. E. (2006). Why minimal guidance during instruction does not work: An analysis of the failure of constructivist, discovery, problem-based, experiential, and inquiry-based teaching. Educational Psychologist, 41(2), 75-86. https://doi.org/10.1207/s15326985ep4102 1

Luckie, D. B., Maleszewski, J. J., Loznak, S. D., \& Krha, M. (2004). Infusion of collaborative inquiry throughout a biology curriculum increases student learning: A four-year study of "teams and streams". Advances in Physiology Education, 28(4), 199-209. https://doi.org/10.1152/advan.00025.2004 
New American Economy. (2017, March 29). Sizing up the gap in our supply of STEM workers. https://research.newamericaneconomy.org/report/sizing-up-the-gap-in-our-supply-ofstem-workers/

Organisation for Economic Co-operation and Development (OECD). (2016). Country notes: Key findings from PISA 2015 for the United States. http://www.oecd.org/pisa/PISA-2015United-States.pdf

Plevyak, L. H. (2007). What do preservice teachers learn in an inquiry-based science methods course? Journal of Elementary Science Education, 19(1), 1-12. https://doi.org/10.1007/bf03173650

Ramnarain, U. D. (2014). Teachers' perceptions of inquiry-based learning in urban, suburban, township and rural high schools: The context-specificity of science curriculum implementation in South Africa. Teaching and Teacher Education, 38, 65-75. https://doi.org/10.1016/j.tate.2013.11.003

Roehrig, G. H., \& Luft, J. A. (2004). Research report: Constraints experienced by beginning secondary science teachers in implementing scientific inquiry lessons. International Journal of Science Education, 26(1), 3-24. https://doi.org/10.1080/0950069022000070261

Saunders, R. (2012). Assessment of professional development for teachers in the vocational education and training sector: An examination of the concerns based adoption model. Australian Journal of Education, 56(2), 182-204. http://doi.org/10.1177/000494411205600206

Savery, J. R. (2006). Overview of problem-based learning: definitions and distinctions. Interdisciplinary Journal of Problem-Based Learning, 1(1). https://doi.org/10.7771/1541-5015.1002

Shotsberger, P. G., \& Crawford, A. R. (1999). On the elusive nature of measuring teacher change: An examination of the stages of concern questionnaire. Evaluation \& Research in Education, 13(1), 3-17. https://doi.org/10.1080/09500799908666942

Shoulders, C., \& Myers, B. (2011). An analysis of national agriscience teacher ambassadors' stages of concern regarding inquiry-based instruction. Journal of Agricultural Education, 52(2), 58-70. https://doi.org/10.5032/jae.2011.02058

Southwest Educational Development Laboratory. (2015). Concerns-based adoption model (CBAM). http://www.sedl.org/cbam/

Sundberg, M. D., \& Moncada, G. J. (1994). Creating effective investigative laboratories for 
undergraduates. Bioscience, 44(10), 698-704. https://doi.org/10.2307/1312513

The Nation's Report Card. (2015). NAEP - 2015 science assessment. https://www.nationsreportcard.gov/science 2015/\#acl/chart loc 1 ?grade=12

Udovic, D., Morris, D., Dickman, A., Postlethwait, J., \& Wetherwax, P. (2002). Workshop biology: Demonstrating the effectiveness of active learning in an introductory biology course. Bioscience, 52(3), 272-281. https://doi.org/10.1641/0006-3568(2002)052[0272:WBDTEO]2.0.CO;2

Warner, A., \& Myers, B. (2011). Agriscience teachers' concern profiles for content area reading strategies. Journal of Agricultural Education, 52(4), 109-122. https://doi.org/10.5032/jae.2011.04109

(C) 2021 by authors. This article is an open access article distributed under the terms and conditions of the Creative Commons Attribution license (http://creativecommons.org/licenses/by/4.0/). 